\title{
The Connexin 43 Regulator Rotigaptide Reduces Cytokine-Induced Cell Death in Human Islets
}

\author{
Seyed Mojtaba Ghiasi ${ }^{1,2}{ }^{\circ}$, Jakob Bondo Hansen ${ }^{3}$, Dan Ploug Christensen ${ }^{4}$, Björn Tyrberg ${ }^{5,6}$ \\ and Thomas Mandrup-Poulsen ${ }^{2, *(D)}$ \\ 1 Section of Cell Biology and Functional Genomics, Division of Diabetes, Endocrinology and Metabolism, \\ Department of Metabolism, Digestion and Reproduction, Faculty of Medicine, Imperial College London, \\ London W12 0NN, UK; s.ghiasi@imperial.ac.uk \\ 2 Department of Biomedical Sciences, University of Copenhagen, 2200 Copenhagen N, Denmark \\ 3 Novo Nordisk Foundation Center for Basic Metabolic Research, University of Copenhagen, \\ 2200 Copenhagen N, Denmark; jbh@embarkbiotech.com \\ 4 Department of Biology, University of Copenhagen, 2200 Copenhagen N, Denmark; znf308@alumni.ku.dk \\ 5 Department of Physiology, Sahlgrenska Academy, Gothenburg University, 40530 Gothenburg, Sweden; \\ bjorn.tyrberg@servier.com \\ 6 Cardiovascular and Metabolic Diseases, Institute de recherche Servier, 92150 Suresnes, France \\ * Correspondence: tmpo@sund.ku.dk; Tel.: +45-30-330-387
}

Received: 29 April 2020; Accepted: 15 June 2020; Published: 17 June 2020

\begin{abstract}
Background: Intercellular communication mediated by cationic fluxes through the Connexin family of gap junctions regulates glucose-stimulated insulin secretion and beta cell defense against inflammatory stress. Rotigaptide (RG, ZP123) is a peptide analog that increases intercellular conductance in cardiac muscle cells by the prevention of dephosphorylation and thereby uncoupling of Connexin-43 (Cx43), possibly via action on unidentified protein phosphatases. For this reason, it is being studied in human arrhythmias. It is unknown if RG protects islet cell function and viability against inflammatory or metabolic stress, a question of considerable translational interest for the treatment of diabetes. Methods: Apoptosis was measured in human islets shown to express Cx43, treated with RG or the control peptide ZP119 and exposed to glucolipotoxicity or IL- $1 \beta+$ IFN $\gamma$. INS- 1 cells shown to lack $C x 43$ were used to examine if RG protected human islet cells via Cx43 coupling. To study the mechanisms of action of Cx43-independent effects of RG, $\mathrm{NO}, \mathrm{IkB} \alpha$ degradation, mitochondrial activity, ROS, and insulin mRNA levels were determined. Results: RG reduced cytokine-induced apoptosis $\sim 40 \%$ in human islets. In Cx43-deficient INS-1 cells, this protective effect was markedly blunted as expected, but unexpectedly, RG still modestly reduced apoptosis, and improved mitochondrial function, insulin-2 gene levels, and accumulated insulin release. RG reduced NO production in Cx43-deficient INS-1 cells associated with reduced iNOS expression, suggesting that RG blunts cytokine-induced NF- $\mathrm{kB}$ signaling in insulin-producing cells in a Cx43-independent manner. Conclusion: RG reduces cytokine-induced cell death in human islets. The protective action in Cx43-deficient INS-1 cells suggests a novel inhibitory mechanism of action of RG on NF- $\mathrm{kB}$ signaling.
\end{abstract}

Keywords: beta cell; inflammation; insulin; NF- KB; gap junctions

\section{Introduction}

By inducing beta cell endoplasmic reticulum stress and apoptosis via the intrinsic mitochondrial pathway, proinflammatory cytokines have been implicated as mediators of beta cell failure and destruction causing type 1 diabetes (T1D) and type 2 diabetes (T2D) [1]. Antagonism of the action of the prototypic proinflammatory cytokine interleukin-1 (IL-1) improves beta cell function in T2D patients [2], 
an effect sustained 39 weeks beyond cessation of the antagonism in responders [3]. Despite a strong preclinical rationale [4], anti-IL-1 monotherapy was ineffective overall in recent-onset T1D. However, IL-1 antagonism did moderate inflammation and caused a 2.5-fold higher secretory function in T1D patients with intermediary beta cell function at baseline [5,6]. Since IL-1-induced beta cell apoptosis is potentiated by other proinflammatory cytokines, such as TNF $\alpha$, IFN $\gamma$, and IL-6, and since anti-TNF therapy improved beta cell function in a small placebo-controlled trial [7], it is likely that a combination of treatments targeting various aspects of signaling caused by the cytokine network is needed to improve the efficacy of anti-cytokine strategies in T1D, as has indeed been demonstrated in animal models [8]. Thus, there is a need for novel safe therapeutic approaches for such combination therapies.

Appropriate pulsatile insulin secretion depends on islet intercellular communication and synchronization [9]. Accordingly, cytokine-mediated de-synchronization of intercellular oscillating calcium fluxes alters the beta cell transcriptome and sensitizes it to a stress-induced impaired secretory function and apoptosis [10]. Gap junctions are intercellular channels composed of two connexin (Cx) hemi-channels in homo- or heterotypic combinations, with each hemi-channel comprising of six Cx subunits [11]. Cx36 is a predominant $C x$ in beta cells and regulates insulin secretion by calcium flux synchronization [11-13]. Other Cxs are also expressed in islets (Cx43 and Cx45 in mice; Cx30.3, Cx31, Cx31.1, Cx31.9, Cx43, and Cx45 in humans), although the function of these Cxs is less characterized [11,14-16]. Cx43 was recently identified as an important regulator of beta cell differentiation [17] and maturation [18], explaining why beta cell-specific knockout of $\mathrm{Cx} 43$, but not of $\mathrm{Cx36}$, reduces the pancreatic insulin content and islet size [19]. However, Cx43 was not found to be expressed on adult beta cells or insulin-producing cell lines [20-22]. Interestingly, Cx43 and Cx32 are expressed on non-endocrine pancreatic cells, and heterotypic channels between, e.g., endothelial cells and islet endocrine cells $[23,24]$ have been implicated in regulating glucose-stimulated islet blood flow [25]. Whole-body Cx36-deficient mice develop beta cell destruction and hyperglycemia, whereas beta cell-specific transgenic Cx36 overexpression protects against single high-dose streptozotocin-induced diabetes and restores islet insulin contents in this model. In addition, proinflammatory cytokines reduce beta cell Cx36 expression, and Cx36 deficiency aggravates cytokine-induced beta-cell toxicity [10]. Therefore, pharmacological targeting of gap junctions has been proposed as a novel approach to rescue and restore the pancreatic beta cell mass from stress-induced apoptosis. An important knowledge gap to guide clinical trials is the demonstration of the importance of the Cx family in human islet apoptosis induced by inflammatory stress.

The peptide rotigaptide (RG) increases intercellular conductance in cardiac muscle cells and restores gap junction intercellular communication (GJIC) in atrial cardiomyocytes of metabolically stressed rats [26]. RG prevents dephosphorylation and thereby uncoupling of Cx43, possibly by acting on yet unidentified protein phosphatases $[27,28]$. In addition, RG dose-dependently increases the Cx43 expression level in rat cardiomyocytes [29]. Interestingly, proinflammatory cytokines downregulate Cx43 expression and inhibit GJIC in human corneal fibroblasts [30] and in mouse astrocytes [31], suggesting that $\mathrm{C} \times 43$ plays a critical role in regulating the GJIC in inflammatory stress in cells. However, the role of Cx43 in the response of pancreatic islet cells to cytokine stress is yet unclear. Here, we had two aims: (1) To investigate if Cx43 plays a role in inflammatory stress-induced human islet cell apoptosis using RG as a Cx43 coupler, and (2) to examine if RG exerts an anti-apoptotic effect via Cx43 in human islets by demonstrating loss-of-function of RG on cytokine-induced apoptosis in Cx43-deficient INS-1 cells.

\section{Results}

\subsection{Rotigaptide Reduces Cytokine-Induced Apoptosis in Cx43-Expressing Human Islets}

As shown in Figure 1A, we found that human and rat islets did express Cx43, whereas INS-1 cells did not, neither in the unchallenged not the cytokine-challenged state. Reanalyzing published human islet single cell sequencing data [32], the expression of connexins apart from Cx36, well-known 
to be expressed in islet endocrine cells, was determined (Figure S1). Endocrine alpha, beta, and delta cells equally expressed Cx31.9, and 32; acinar and ductal cells equally expressed Cx26, 31, 32, and 43; ductal cells also expressed Cx30.3 and Cx45; pancreatic stellate cells expressed Cx31.9, 43, and 45; whereas endothelial cells were only found to express $\mathrm{C} \times 43$ (with the caveat that the number of passenger endothelial cells in cultured human islets is low). We next examined whether the Cx43 activator RG protects human islets from inflammatory-induced cell death. As expected, the cytokine combination increased islet apoptosis by two-fold after 4 days of exposure (Figure 1B). Neither RG nor CP in the absence of cytokines caused apoptosis in human islets. Interestingly, RG significantly reduced cytokine-induced islet apoptosis by $40 \%$, whereas the control peptide did not significantly change cytokine-induced apoptosis.

A

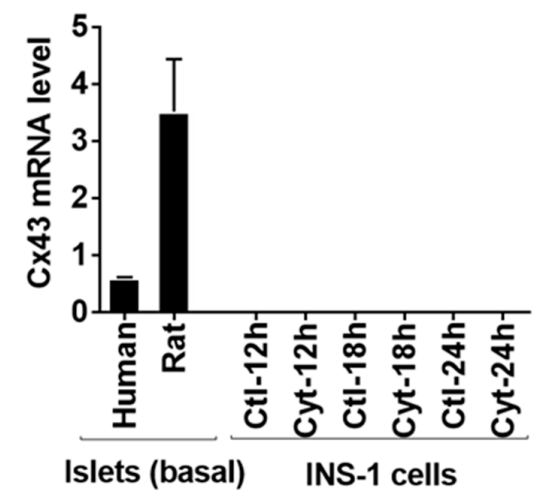

B

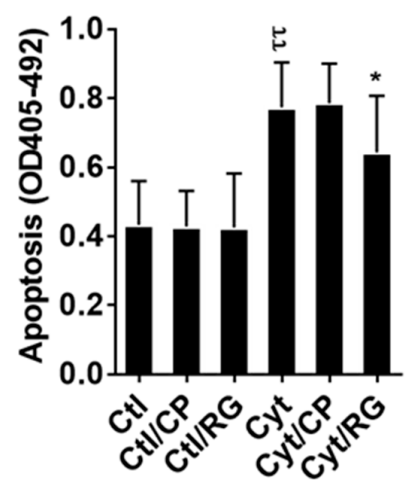

Figure 1. Rotigaptide reduces cytokine-induced apoptosis in Cx43-expressing human islets. Fifty pancreatic islets per condition were pre-incubated with or without $500 \mathrm{nM}$ rotigaptide/ZP123 (RG) or control peptide ZP119 (CP) for one hour in the presence or absence of cytokine mixture (300 pg/mL IL-1 $\beta+10 \mathrm{ng} / \mathrm{mL}$ IFN $\gamma+10 \mathrm{ng} / \mathrm{mL}$ TNF $\alpha$; Cyt) for 4 days. (A) The Cx43 expression level was determined in untreated human and rat islets, and in INS-1 cells exposed to the cytokine combination $(150 \mathrm{pg} / \mathrm{mL}$ IL- $1 \beta+0.1 \mathrm{ng} / \mathrm{mL}$ IFN $\gamma$ ) using specific primers with qPCR. The expression of the genes normalized to HPRT1 was calculated by $-\Delta$ Ct. (B) Apoptosis was measured by Roche cell death assay according to the manufacturer's protocol. Data are means \pm SEM of $n=5$ donor human islets. ${ }^{*} \leq 0.05, \tau \tau \leq 0.01$. The symbols $\tau$ and ${ }^{*}$ indicate the Bonferroni-corrected paired $t$-test values of cytokine (Cyt) exposure versus control (CTL) and Cyt exposure versus exposure to Cyt and RG, respectively. NS: not significant.

\subsection{Rotigaptide Ameliorates Cytokine-Induced Apoptosis Associated with Improved Mitochondrial Function in} Cx43-Deficient INS-1 Cells

Since the rat insulin-producing INS- 1 cells did not express $\mathrm{Cx} 43$, and Cx43 was not induced by cytokine exposure for 12-24 h (Figure 1A), INS-1 cells were used a natural Cx43 loss-of-function 
cell model to investigate $\mathrm{C} x 43$-independent effects of rotigaptide on insulin-producing cells. IL-1 $\beta$ concentrations above $15 \mathrm{pg} / \mathrm{mL}$ combined with a fixed concentration of $0.1 \mathrm{ng} / \mathrm{mL}$ IFN $\gamma$ dose-dependently induced apoptosis in INS-1 cells, with a peak three-fold induction at $150 \mathrm{pg} / \mathrm{mL}$ IL-1 $\beta$ (Figure 2A). RG or CP did not by themselves affect INS-1 cell apoptosis. We anticipated that rotigaptide would not protect $\mathrm{Cx} 43$-deficient insulin-producing INS-1 cells against cytokine-induced apoptosis to the same extent as that observed in human islets. Unexpectedly, RG but not CP modestly but significantly reduced apoptosis in cytokine-exposed cells by $\sim 10 \%$ at IL-1 $\beta$ concentrations above $15 \mathrm{pg} / \mathrm{mL}$. Exposure of INS-1 cells to glucolipotoxic conditions significantly increased apoptosis by 3.8-fold, but this was counteracted neither by RG nor CP.

A

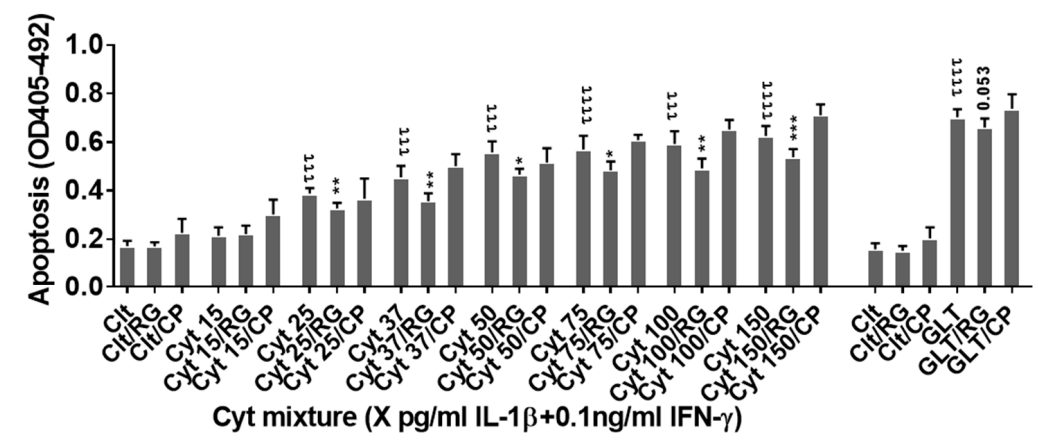

B

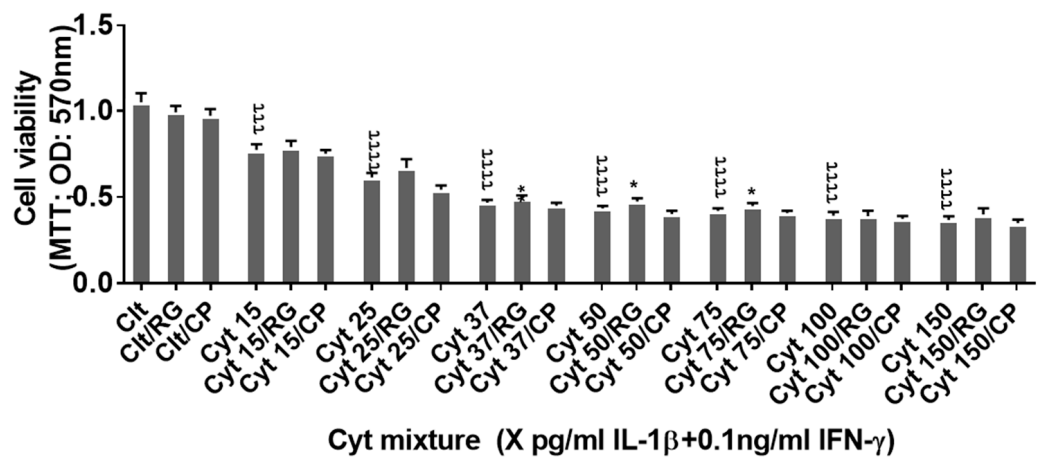

Figure 2. Rotigaptide ameliorates inflammation-induced apoptosis associated with improved mitochondrial function in Cx43-deficient INS-1 cells. INS-1 cells were pre-incubated with or without $100 \mathrm{nM}$ rotigaptide (RG) or control peptide ZP119 (CP) for one hour in the presence or absence of cytokine combination (IL-1 $\beta$ in the concentrations indicated $+0.1 \mathrm{ng} / \mathrm{mL} \mathrm{IFN} \gamma$; Cyt) or glucolipotoxicity $(0.5 \mu \mathrm{M}$ palmitate $+25 \mathrm{mM}$ glucose; GLT) for $24 \mathrm{~h}$. (A) Apoptosis was measured by Roche cell death assay according to the manufacturer's protocol. (B) Mitochondrial function was determined using MTT assay. Results are means \pm SEM of $n=6$ independent experiments. ${ }^{*}$ or $\tau \leq 0.05,{ }^{* *}$ or $\tau \tau \leq 0.01$, *** or $\tau \tau \tau \leq 0.001, \tau \tau \tau \tau \leq 0.0001$. The symbols $\tau$ and ${ }^{*}$ star indicate the Bonferroni-corrected paired $t$-test values of cytokine (Cyt) exposure versus control (CTL) and Cyt exposure versus exposure to Cyt and RGs, respectively. NS: not significant.

Since cytokines induce mitochondrial stress in pancreatic beta cells, we then investigated if the Cx43-independent action of RG was associated with the prevention of cytokine-induced mitochondrial dysfunction. IL-1 $\beta$ dose-dependently reduced mitochondrial function by $64 \%$ at $150 \mathrm{pg} / \mathrm{mL} \mathrm{IL-} 1 \beta$. RG, but not $\mathrm{CP}$, slightly but significantly improved mitochondrial function in cytokine-exposed cells at 37 , 50, and $75 \mathrm{pg} / \mathrm{mL}$ IL-1 (Figure 2B). 


\subsection{Rotigaptide Reduces Neither Cytokine nor Glucolipotoxicity-Induced ROS Production in INS-1 Cells}

We next asked if the improved mitochondrial function caused by RG was associated with reduced ROS production. IL-1 $\beta$ dose-dependently increased INS-1 cell ROS production (Figure 3A), which was unaffected by RG. Additionally, ROS production in response to glucolipotoxic conditions was unaffected by RG. Since oxidative/nitroxidative stress induced by proinflammatory mediators causes dysfunction of mitochondrial complexes by inhibiting their transcription [33], we explored if RG would prevent cytokine-induced mitochondrial dysfunction. We therefore measured the mRNA levels of two genes encoding key subunits of the mitochondrial complex I and IV: NADH-dehydrogenase subunit 2 (ND2) and cytochrome C oxidase II (Sco2), respectively. Cytokines downregulated ND2, and there was a trend for downregulation of Sco2 ( $p=0.09)$, but RG did not restore these changes (Figure 3B).

A

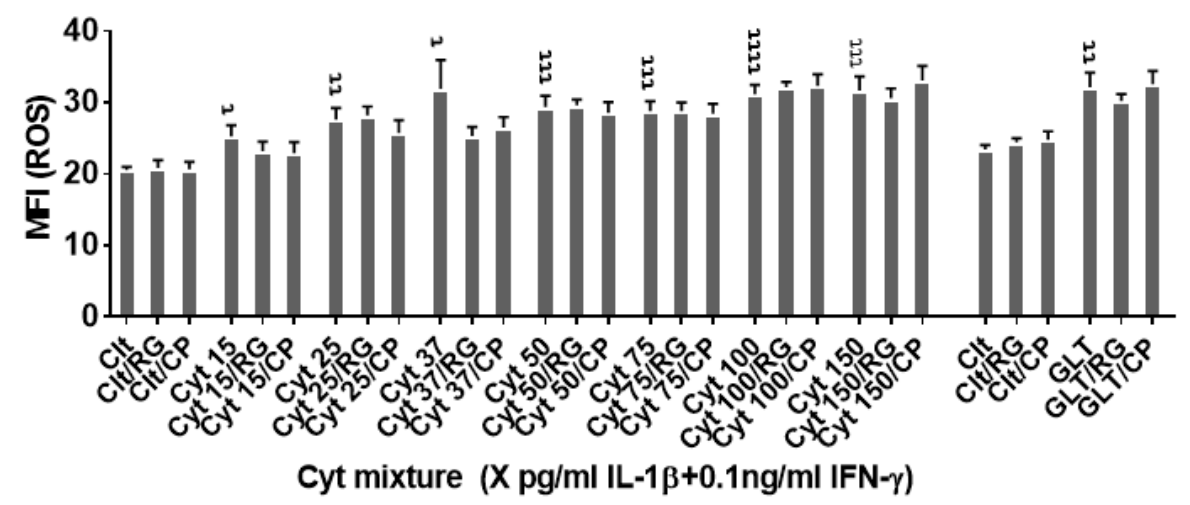

B

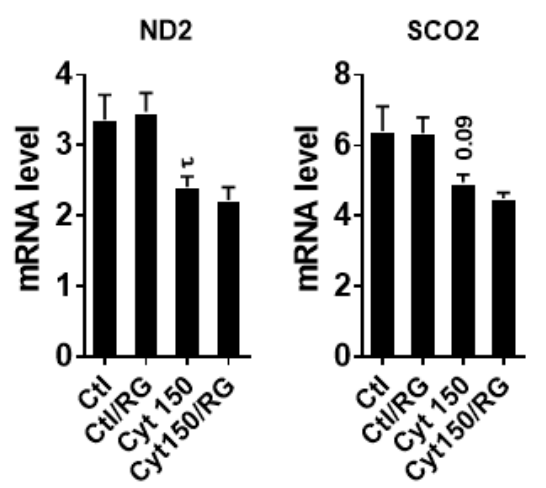

Figure 3. Rotigaptide does not reduce inflammatory or glucolipotoxicity-induced intracellular ROS in INS-1 cells. INS-1 cells were pre-incubated with or without $100 \mathrm{nM}$ Rotigaptide (RG) or control peptide ZP119 (CP) for one hour in the presence or absence of cytokine mixture (IL-1 $\beta$ in the concentrations indicated $+0.1 \mathrm{ng} / \mathrm{mL}$ IFN $\gamma$; Cyt $)$ or glucolipotoxicity $(0.5 \mu \mathrm{M}$ Palmitate $+25 \mathrm{mM}$ glucose; GLT) for $18 \mathrm{~h}$. (A) Cellular ROS level was determined using DCF assay and presented as MFI. (B) The mRNA level of NADH-dehydrogenase subunit 2 (ND2) and Cytochrome C Oxidase II (Sco2) genes was determined using specific primers with $q P C R$. The expression of the genes normalized to HPRT1 was calculated by $-\triangle \mathrm{Ct}$. Data are the means $\pm \mathrm{SEM}$ of $\mathrm{N}=6$ (for $\mathrm{A}$ ) $/ \mathrm{N}=4$ (for B) independent experiments. $\tau \leq 0.05, \tau \tau \leq 0.01, \tau \tau \tau \leq 0.001, \tau \tau \tau \tau \leq 0.0001$. The symbols $\tau$ indicate the Bonferroni-corrected paired $t$-test values of cytokine (Cyt) exposure versus control (CTL) and Cyt exposure versus exposure to Cyt and RG, respectively. ROS: reactive oxygen species, MFI: mean fluorescent intensity, DCF: dichlorodihydrofluorescein. 


\subsection{Rotigaptide Reduces Nitroxidative Stress Independently of Cx43}

Next, we asked if RG inhibited nitroxidative stress in INS-1 cells. IL-1 $\beta$ significantly induced NO production in INS-1 cells (Figure 4A), which was reduced by RG but not CP at 100 and $150 \mathrm{pg} / \mathrm{mL}$ IL-1. IL-1 $\beta$ dose-dependently increased iNOS mRNA levels, which were reduced by RG but not CP at 100 and $150 \mathrm{pg} / \mathrm{mL}$ IL-1 (Figure 4B).

A

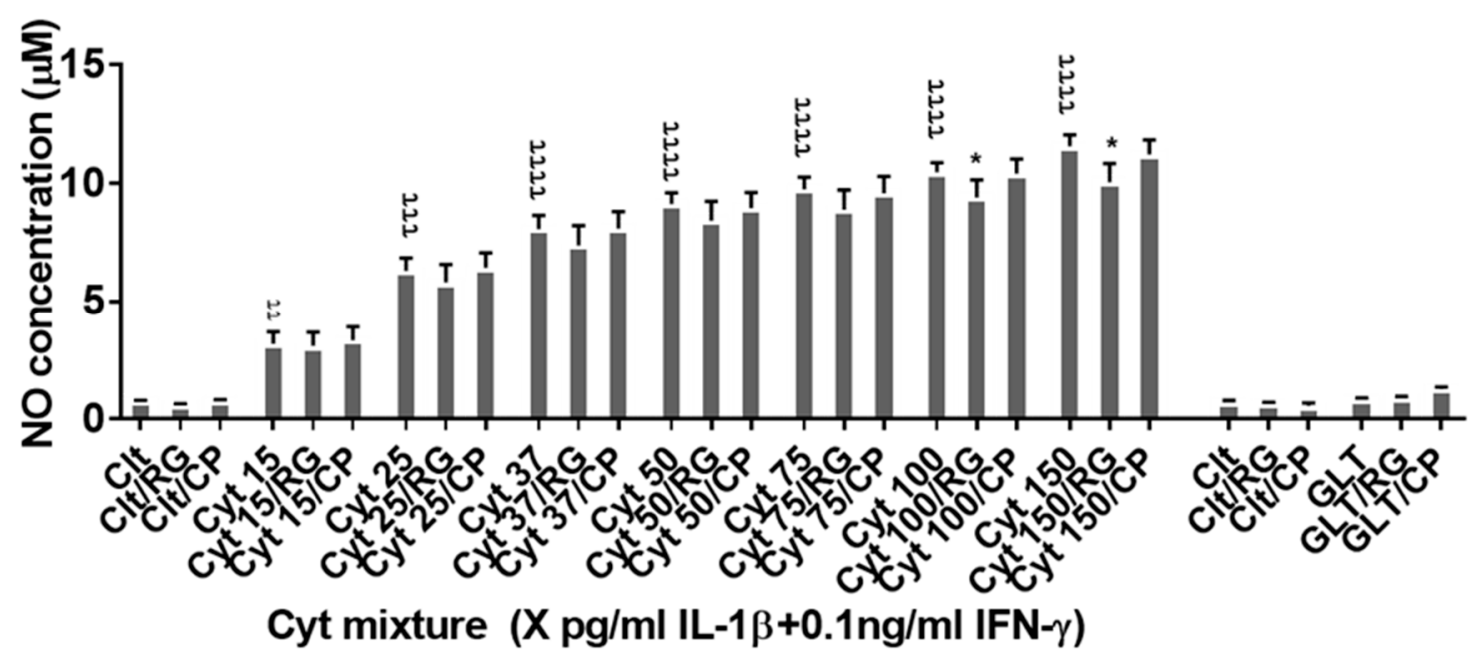

B

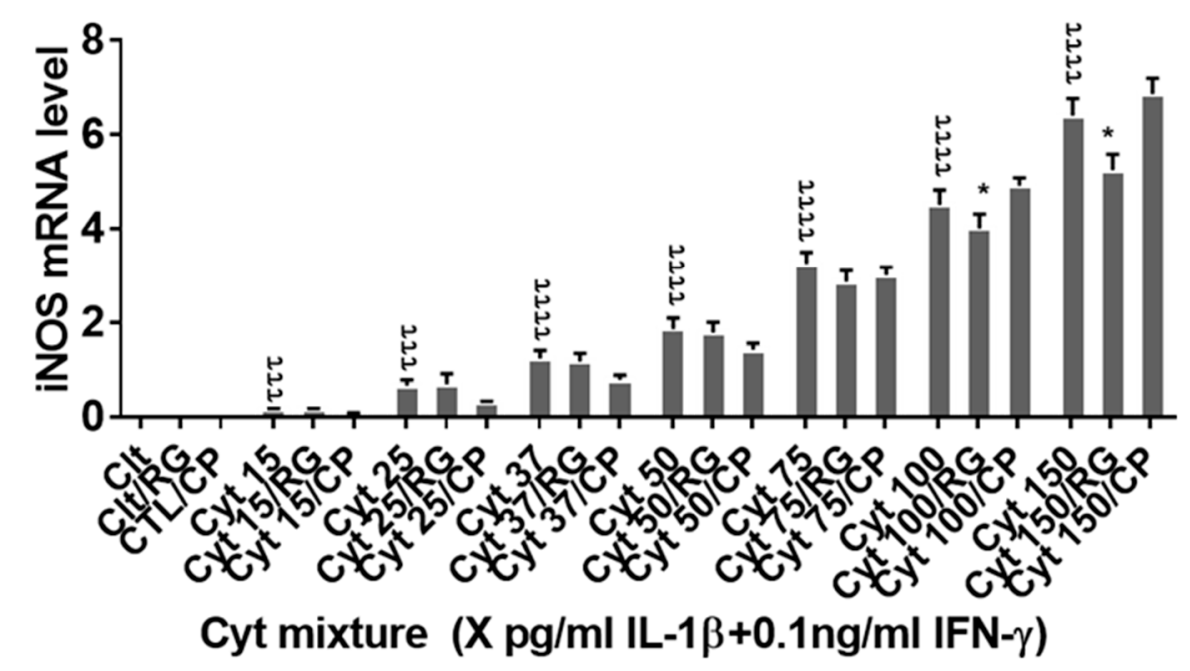

Figure 4. Cont. 
C

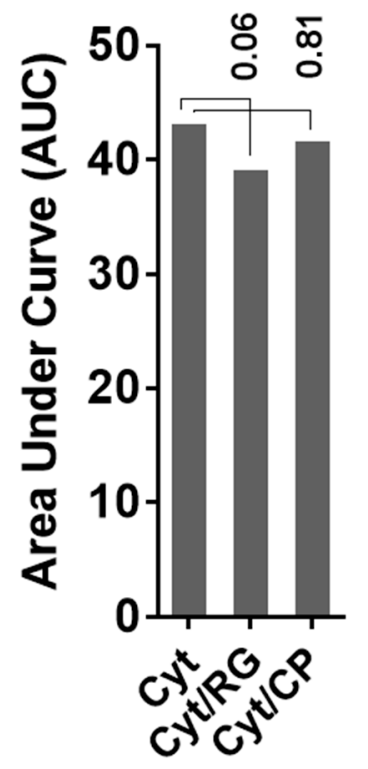

D

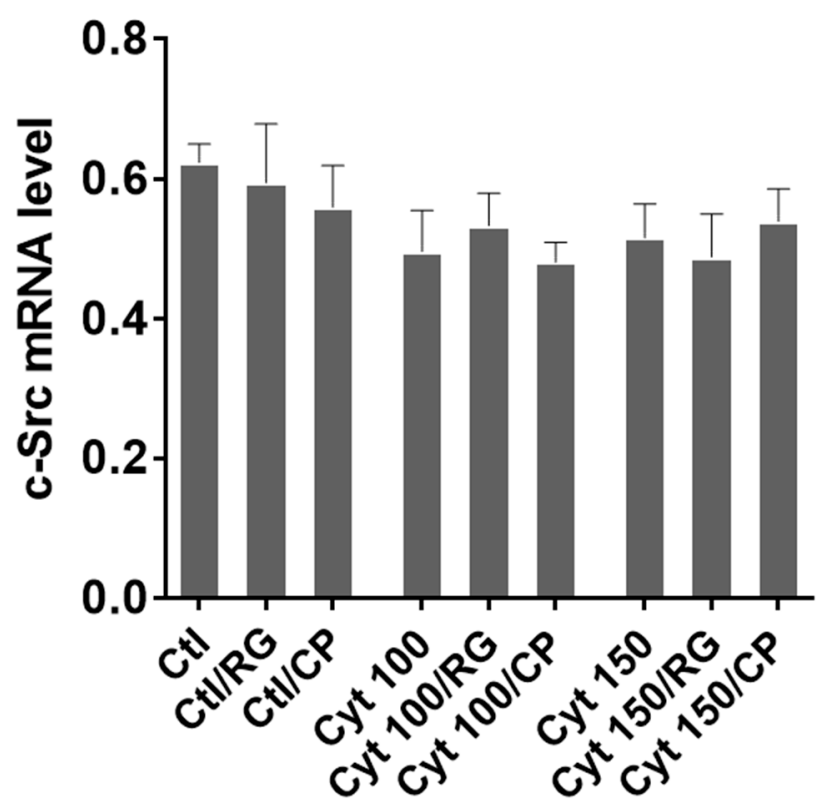

Figure 4. Rotigaptide reduces nitroxidative stress in INS-1 cells. INS-1 cells were pre-incubated with or without $100 \mathrm{nM}$ rotigaptide (RG) or control peptide ZP119 (CP) for one hour in the presence or absence of cytokine mixture for $24 \mathrm{~h}(\mathbf{A}), 6 \mathrm{~h}$ (B,D), or in a time course of 5, 10, 15, 20, 25, 30, or $45 \mathrm{~min}$ (C). (A) Accumulated nitrite was measured with Griess reagent in the supernatant. (B,D) iNOS and c-Src mRNA levels were determined by qPCR. The expression of iNOS and c-Src normalized to HPRT1 was calculated with $-\Delta$ Ct. (C) Immunoblot analysis of the time course of cytokine-induced IkB $\alpha$ degradation in the presence or absence of RG or CP was quantified with ImageJ software and normalized to tubulin. Data are means \pm SEM of $n=6$ (for $\mathbf{A}, \mathbf{B}, \mathbf{D}) / n=3$ (for $\mathbf{C}$ ) independent experiments. * $\leq 0.05$, $\tau \tau \leq 0.01, \tau \tau \tau \leq 0.001, \tau \tau \tau \tau \leq 0.0001$. The symbols $\tau$ and * indicate the Bonferroni-corrected paired t-test values of cytokine (Cyt) exposure versus control (CTL) and Cyt exposure versus exposure to Cyt and RG, respectively. NS: not significant. AUC: area under curve, NO: nitric oxide, iNOS: inducible nitric oxide synthase, HPRT1: Hypoxanthine-guanine phosphoribosyltransferase 1.

We next investigated if rotigaptide mitigated nitroxidative stress by impeding IkB $\alpha$ degradation. Cytokines caused IkB $\alpha$ degradation in a time-dependent manner (Figure $4 \mathrm{C}$ ). There was a strong trend ( $p=0.06)$ for RG but not CP diminishing the AUC for IkB $\alpha$ degradation. Since cytokine-induced c-Src levels might be higher in Cx43-deficient cells and since c-Src binds and thereby acts as a sink for $\mathrm{IkB} \alpha[34,35]$, we investigated c-Src expression in INS-1 cells exposed to cytokines in the presence or absence of RG or CP. As shown in Figure 4D, c-Src mRNA levels were unaffected by cytokines and RG.

Taken together, the data suggest that rotigaptide reduces nitroxidative stress independently of its action on Cx43 activity.

\subsection{Rotigaptide Ameliorates High-Concentration Cytokine-Induced Inhibition of Insulin Secretion and Reduction of Insulin mRNA in INS-1 Cells}

To explore if RG restores cytokine-mediated inhibition of insulin biosynthesis and secretion, we measured the accumulated insulin secretion and insulin mRNA in INS-1 cells. RG but not CP significantly improved insulin secretion in INS-1 cells at 150 pg/mL IL-1 $\beta$ (Figure 5A). 
A

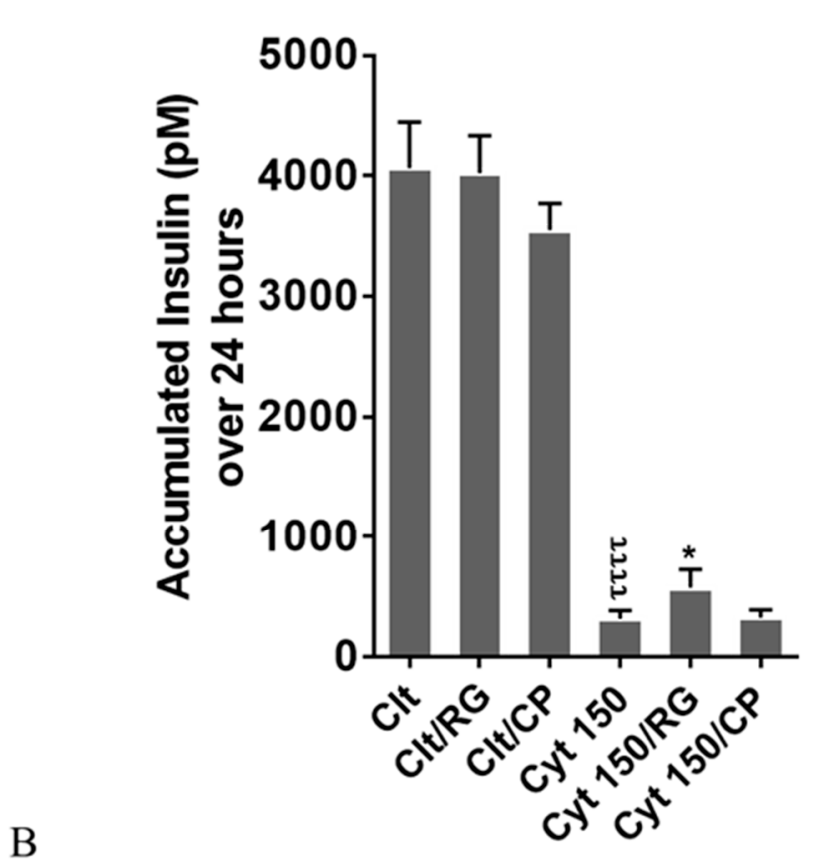

Ins-1

Ins-2

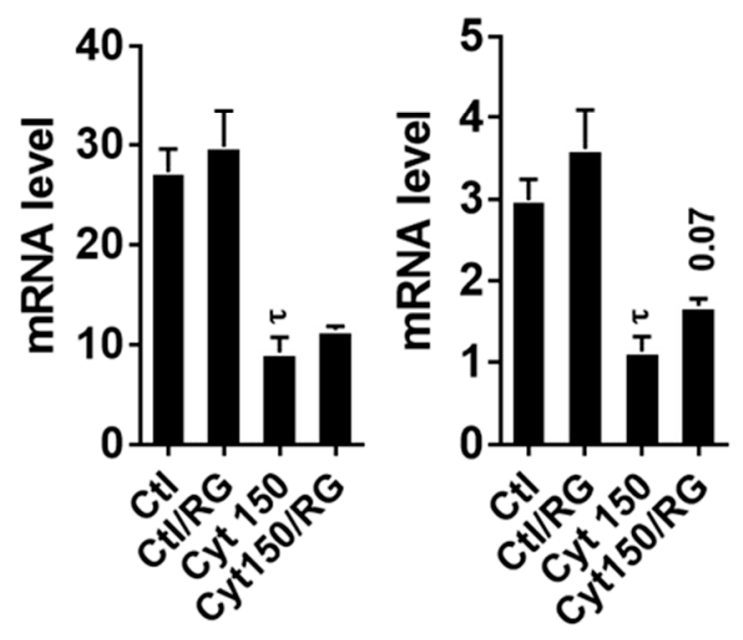

Figure 5. Rotigaptide ameliorates cytokine-induced inhibition of insulin secretion and reduction of insulin mRNA in INS-1 cells. INS-1 cells were pre-incubated with or without $100 \mathrm{nM}$ rotigaptide (RG) or control peptide ZP119 (CP) for one hour in the presence or absence of cytokine mixture for 24 (A) or $18 \mathrm{~h}$ (B). (A) Accumulated insulin was measured by competitive insulin ELISA in the supernatant collected. (B) The mRNA level of insulin-1 (Ins-1) and insulin-2 (Ins-2) genes was determined by qPCR. The expression of the genes normalized to HPRT1 was calculated by $-\Delta \mathrm{Ct}$. Data are the means \pm SEM of $n=6$ (for A) $/ n=4$ (for B) independent experiments. * or $\tau \leq 0.05, \tau \tau \tau \tau \leq 0.0001$. The symbols $\tau$ and * indicate the Bonferroni-corrected paired t-test values of cytokine (Cyt) exposure versus control (CTL) and Cyt exposure versus exposure to Cyt and RG, respectively. NS: not significant.

Finally, we studied if this partial recovery of secreted insulin was due to an increase in the insulin mRNA level. qPCR analysis confirmed significant cytokine-mediated reductions in the mRNA levels of insulin-1 and insulin-2. A trend ( $p=0.07)$ for partial reversal of the inhibition in insulin-2 but not insulin-1 levels was observed after RG treatment (Figure 5B). 


\section{Discussion}

We show here that the Cx43 activator RG reduces proinflammatory cytokine-induced apoptosis in human islets, shown to have low levels of Cx43 expression. Surprisingly, this protective effect was not abrogated in INS-1 cells, shown to be Cx43 deficient (Figure 1A) [20,21]. In these cells, RG still modestly but significantly reduced apoptosis, and also improved mitochondrial function, insulin-2 gene levels, and accumulated insulin release. RG reduced NO production in Cx43-deficient INS-1 cells associated with reduced iNOS expression and IkB $\alpha$ degradation, suggesting that RG blunts cytokine-induced NF- $\mathrm{KB}$ signaling in insulin-producing cells in a Cx43-independent manner. High glucose downregulates $\mathrm{C} \times 43$ and inhibits the protein-protein interaction between c-Src and $\mathrm{Cx} 43$ in glomerular mesangial cells, thereby promoting binding of c-Src to $\operatorname{IkB} \alpha$, in turn activating the NF- $\mathrm{kB}$ pathway $[34,35]$. These observations raise the intriguing possibility that RG may inhibit NF- $\mathrm{KB}$ signaling by enhancing $\mathrm{C} \times 43$ expression and activity, but this remains to be shown.

An important question is how RG intercepts NF- $\mathrm{kB}$ activation in the absence of Cx43. In Cx43-deficient cells, a lack of Cx43/c-Src interaction would be expected to lead to higher c-Src availability for $\mathrm{I} k \mathrm{~B} \alpha$ binding, thereby priming the cells for cytokine-triggered NF-kB activation. We investigated c-Src expression in INS-1 cells and were unable to show altered c-Src mRNA levels caused by either cytokines or RG. In Cx43-competent cells, however, this mechanism would be expected only to play a role under conditions of inhibited Cx43 expression, such as those induced by high glucose [34,35]. The lack of protection of RG on high glucose and high lipid toxicity in INS-1 cells may be explained by the absence of $\mathrm{Cx} 43$, and these experiments should therefore be repeated in human islets, in which RG would be expected to counteract a glucose-mediated reduction in Cx43 expression.

Given the lack of beta cell Cx43 expression shown by others [17-19,22] and in our single-cell RNA-seq analysis of human islets (Figure S1), but that heterotypic channels can be formed between Cx43-positive non-endocrine pancreatic cells and Cx43-negative islet endocrine cells expressing other connexins, such as $\mathrm{C} \times 36$ or $\mathrm{C} \times 32$, we suggest that RG promotes the coupling of $\mathrm{C} \times 43$ expressed on islet endothelial or pancreatic stellate cells to other islet endocrine cell connexins to form heterotypic channels that promote islet cell survival.

The strengths of this study were the use of human islets to demonstrate the protective effect of RG against cytokine-induced apoptosis, and the inclusion of a scrambled peptide as a control for RG. We also took advantage of INS-1 cells shown to lack Cx43 expression as a 'natural' Cx43 knock-out model (Figure 1A) [20,21], thereby avoiding the risk for transfection artifacts related to small hairpin (sh) RNA knock-down or CRISPR knock-out.

A limitation was the restricted amounts of human islets available to us for these studies, precluding more mechanistic investigations, such as $\mathrm{C} \times 43$ protein expression and cellular localization, $\mathrm{C} \times 43$ channel activity, $\mathrm{Ca}^{2+}$ flux synchronization, and studies of glucose-stimulated insulin secretion. Electromobility shift assay, iNOS promotor chromatin immunoprecipitation, or luciferase-based NF- $\kappa B$ reporter assay would help define if NF- $\mathrm{kB}$ promoter binding or NF- $\mathrm{KB}$ transcriptional activity is reduced in rotigaptide-treated islets exposed to cytokines.

Rotigaptide is known to increase the $\mathrm{C} \times 43$ half-life in cardiomyocytes by slowing its trafficking and proteasomal degradation $[29,36,37]$. However, proof of $C \times 43$ dependence of such effects of RG in human islets would require knock-down or knock-out of $\mathrm{Cx} 43$, which is not effective in intact islets but requires islet dispersion into monolayers, thereby disrupting the normal cell-to-cell contact and communication. This study does not demonstrate that RG-mediated prevention of cytokine-induced apoptosis is beta cell specific. Such studies would be demanding, since the sorting of islet cells and even reassembly into beta cell-enriched pseudo-islets would eliminate interaction with Cx43-expressing non-endocrine cells. However, since cytokine-mediated islet cell apoptosis is selective for beta cells $[1,38]$ it is likely that the reduction of human islet cell apoptosis by RG is related to reduced beta cell death. Further research is needed to clarify if these effects contribute to the protective action of rotigaptide in human islets.

When added to the fact that Cx43 is required for beta cell differentiation and maturation [19], our observations highlight the translational potential of RG as a novel approach to prevent inflammatory 
islet cell failure and apoptosis in diabetes and warrant further preclinical studies. The notion that RG may have a dual protective action related to its known activity as a Cx43 activator and to a novel Cx43-independent inhibiting action on NF- $\mathrm{kB}$ activation makes RG an attractive candidate for monoor combination therapy in diabetes.

\section{Methods}

\subsection{Reagents}

Recombinant rat (rr) IL-1 $\beta$, mouse (rm) IFN $\gamma$, human (rh) IFN $\gamma$, and rhTNF $\alpha$ were purchased from R\&D Systems (Minneapolis, Macheray-Nagel, USA). Rotigaptide (RG; ZP123) and control scrambled inert hexapeptide (CP; ZP119) were provided by Zealand Pharma (Soeborg, Denmark).

\subsection{Cell Culture and Exposures}

The rat INS-1 cell line (generously provided by Claes Wollheim, University of Geneva, Geneva, Switzerland) known not to express Cx43 [20,21] was tested negative for Mycoplasma and maintained as previously described [38,39]. INS-1 cells were seeded in 6-well plates $\left(1 \times 10^{6}\right.$ cells/well for RNA isolation), 48-well plates (50,000 cells/well for cell death assay in duplicate), or 96-well plates (30,000 cells/well for MTT assay and ROS assay) (all plates from NUNC, Roskilde, Denmark). After $48 \mathrm{~h}$ of pre-incubation, cells were treated for the time periods indicated with or without $100 \mathrm{nM}$ rotigaptide or $\mathrm{CP}$, for one hour and then cultured with or without cytokine mixture $(\mathrm{Cyt})$ at the concentrations indicated in the figures or figure legends, or in glucolipotoxic conditions $(0.5 \mu \mathrm{M}$ palmitate conjugated with $0.1 \%$ albumin as described in [40] $+25 \mathrm{mM}$ glucose; GLT) for $24 \mathrm{~h}$. Two concentrations of 100 and $500 \mathrm{nM}$ rotigaptide were tested in INS-1 cells. No differences in the efficacy on cell death and NO were noted, and therefore $100 \mathrm{nM}$ was selected, in agreement with [29].

\subsection{Human Islet Culture and Exposures}

Islets from five human heart-beating organ donors ( $>80$ purity, donor characteristics listed in Table 1) were isolated by the European Consortium for Islet Transplantation (ECIT) in Milan, Italy under local approval and received in fully anonymous form, were cultured in $10 \%$ fetal bovine serum (FBS), $1 \%$ penicillin/streptomycin $(\mathrm{P} / \mathrm{S})$, and $5.6 \mathrm{mM}$ glucose at $5 \% \mathrm{CO}_{2}$ and $37^{\circ} \mathrm{C}$ as described previously [41]. There were no apparent differences in the results obtained with islets from male or female donors, and data were therefore combined.

Table 1. Characteristics of human donors of pancreatic islets.

\begin{tabular}{ccccc}
\hline No. & Lab Code & Gender & Age & BMI \\
\hline 1 & HE-5-15 & F & 22 & 22.8 \\
\hline 2 & HE-10-16 & F & 60 & 23.6 \\
\hline 3 & HE-15-16 & M & 34 & 23.1 \\
\hline 4 & HE-17-16 & M & 50 & 24.8 \\
\hline 5 & HE-2-17 & M & 52 & 25.1 \\
\hline
\end{tabular}

Fifty human islets were pre-cultured in RPMI supplemented with $2 \%$ human serum (Life Technologies, Naerum, Denmark), 1\% penicillin/streptomycin (P/S), and $5.6 \mathrm{mM}$ glucose for $24 \mathrm{~h}$, treated with or without $500 \mathrm{nM}$ rotigaptide or control peptide for one hour and then exposed to cytokine mixture ( $300 \mathrm{pg} / \mathrm{mL}$ rrIL-1 $\beta+10 \mathrm{ng} / \mathrm{mL}$ rhIFN $\gamma+10 \mathrm{ng} / \mathrm{mL} \operatorname{rhTNF} \alpha$ ) or control medium for 4 days. 


\subsection{Apoptosis and Cell Viability Assays}

For the apoptosis assay carried out in duplicate independent cultures, DNA/histone complexes released from the nucleus to the cytosol were measured using a Roche cell death assay kit (Roche, Mannheim, Germany) according to the manufacturer's protocol. As a surrogate of cell viability, mitochondrial function was measured in duplicate by the MTT assay in which water-soluble MTT (3-(4,5-dimethylthiazol-2-yl)-2,5-diphenyltetrazolium-bromide) was converted by normal cells to an insoluble formazan salt with an optical density (OD) read at $570 \mathrm{~nm}$.

\subsection{Nitric Oxide (NO) Assay}

As a surrogate of nitric oxide production, accumulated nitrite was measured in duplicate samples from two independent parallel cultures. Supernatants $(100 \mu \mathrm{L})$ from the wells used for the INS-1 cell apoptosis assay were mixed with an equal volume of the Griess reagent (one part $0.1 \%$ naphtylethylene diamine dihydrochloride and one part 1\% sulfanilamide in 5\% H3PO4 (Merck, Darmstadt, Germany), and read at $550 \mathrm{~nm}$ in a plate reader (Thermo Scientific, Naerum, Denmark). The nitrite concentration was calculated using a standard curve of $0.5-40 \mu \mathrm{M}$ concentrations of $\mathrm{NaNO}_{2}$ (Merck, Darmstadt, Germany) as described [42].

\subsection{Reactive Oxygen Species (ROS) Assay}

ROS was measured in triplicate independent parallel cultures by the 5-(and-6)-chloromethyl-20, 70-dichlorodihydrofluorescein (H2DCFDA) (Invitrogen, Naerum, Denmark) probe as previously described [43]. Fluorescence was read at excitation $495 \mathrm{~nm} / \mathrm{emission} 527 \mathrm{~nm}$ and results shown as the delta fluorescence for the time interval of $90-45 \mathrm{~min}$.

\subsection{Real-Time Quantitative RT-PCR}

Total RNA was extracted using the Nucleo-Spin kit (Macheray-Nagel, Bethlehem, USA) according to the manufacturer's instructions. The quality and quantity of the extracted RNA was assessed using a NanoDrop-1000 (Thermo Scientific). In total, $500 \mathrm{ng}$ of total RNA was used for cDNA synthesis with the iScript ${ }^{\mathrm{TM}}-\mathrm{cDNA}$ Kit (BioRad, Copenhagen, Denmark). Real-time qPCR was performed on $12 \mathrm{ng}$ cDNA in triplicate with SybrGreen PCR mastermix (Life Technologies, Naerum, Denmark) and specific primers (Table 2) and run in a Real-Time PCR machine (Applied Biosystems, Naerum, Denmark). The gene expression level was normalized to HPRT1 through $-\Delta \mathrm{Ct}$ analysis [44].

Table 2. Rat primer sequences.

\begin{tabular}{ccc}
\hline & \multicolumn{2}{c}{ Rat Primers } \\
\hline Target & Forward & Reverse \\
\hline iNOS & CACCACCCTCCTTGTTCAACA & CAATCCACAACTCGCTCCAA \\
Ins-1 & TCTGCTCCCTCTACCAACTG & TGCTCATTCAAAGGCTTTATCAT \\
Ins-2 & CCCTAAGTGACCAGCTACAG & CCGCGGATCCACAGGGC \\
HPRT1 & GCAGACTTTGCTTCCTT & GATGAGGAATACAATTATTAGGGTGTG \\
Sco2 & TGGCTTACCCATTTCAACTTGG & CAATCCTACTCATATTAGGAGTAAGT \\
ND2 & AAACCCAATCACCCTAATCATTA & CATGCCTGAAGCAATCTGAG \\
Cx43 & GGCCCAAGTCATGAAGAAAC & TCATGTCCAGCAGCAACTTT \\
\hline & CGCAATTACAACAAGCAAGC & \\
\hline Target & Human Primers & Reverse \\
\hline Cx43 & ATGAGCAGTCTGCCTTTCGT & TCTGCTTCAAGTGCATGTCC \\
HPRT1 & ATG CTG AGG ATT TGG AAA GG & TAA TCC AGC AGG TCA GCA AA \\
\hline
\end{tabular}




\subsection{Western Blot Analysis}

Cells were lysed on ice with NP-40 lysis buffer containing protease inhibitor cocktail (Life Technologies) and stored in a -20 freezer. Lysates were adjusted for protein concentration with the Bradford assay according to the manufacturer's protocol (BioRad, Copenhagen, Denmark), and $50 \mu \mathrm{g}$ of protein separated by 4-20\% SDS-PAGE, and blotted on PDVF membrane (BioRad, Copenhagen, Denmark). The membranes were stained with anti-IkB (Santa Cruz, Heidelberg, Germany) and alpha-tubulin (Sigma, Copenhagen, Denmark) antibodies and developed with the chemiluminescence detection system Super Signal (Life Technologies, Naerum, Denmark) as previously described [45]. Light emission was captured using an Alphaimager system (Alpha Innotech, MultiImage III, Broager, Denmark). Band density was quantified using ImageJ software.

\subsection{Insulin Assay}

Supernatants (1:200 dilution) collected from the INS-1 cell apoptosis assay experiments were used for the measurement of accumulated insulin using the insulin competitive ELISA assay in duplicate samples from two independent parallel cultures as described [46], except that the enzyme substrate 1-step Ultra TMB (3,3' , 5,5;-tetramethylbenzidine) (Life Technologies, Naerum, Denmark) was used here.

\subsection{Single-Cell RNA-Seq of Human Pancreatic Islets}

The expression of genes in islet cell types was determined by reanalyzing published human islet single-cell sequencing data (donor information in EBI accession number: MTAB-5061) [32] as previously described [47].

\subsection{Statistical Analysis}

Data are presented as means \pm SEM, and comparisons between different groups were carried out by ANOVA analysis, followed by Student's paired $t$ test using the GraphPad Prism version 6 (La Jolla, CA, USA). Bonferroni-corrected $p$-values $\leq 0.05$ were considered as significant and $\leq 0.10$ as a trend.

\section{Conclusions}

RG reduces cytokine-induced cell death in human islets, likely by preventing Cx43 uncoupling. RG conferred protection against inflammatory assault even in Cx43-deficient INS-1 cells, suggesting a novel inhibitory mechanism of action of RG on NF- $\mathrm{kB}$ signaling. These observations support further development of RG as a novel therapy to protect the islet functional mass in diabetes due to its dual protective action on key islet cell pro-apoptotic pathways.

Supplementary Materials: The following are available online at http://www.mdpi.com/1422-0067/21/12/4311/s1.

Author Contributions: S.M.G. and T.M.-P. were initiators of the study and developed the protocols for the experiments. S.M.G., J.B.H. and D.P.C. conducted the experiments. B.T. performed the bioinformatics analysis of single-cell RNA sequencing data. S.M.G. performed the statistical analysis, constructed figures and tables and wrote the first draft of the manuscript All authors discussed data and edited the manuscript. All authors have read and agreed to the published version of the manuscript.

Funding: This project was funded by Danish Diabetes Academy (DDA), Zealand Pharma A/S and Department of Biomedical Sciences (BMI), University of Copenhagen, the Augustinus Foundation and the Bjarne Jensen Foundation.

Acknowledgments: We appreciate European Consortium for Islet Transplantation (ECIT), Milan, Italy, for providing donor human islets and Zealand Pharma A/S for providing the ZP123 and ZP119 peptides. Rie Schultz Hansen and Adam Steensberg are thanked for helpful advice and information regarding the peptides.

Conflicts of Interest: The authors declare no conflict of interest. BT is employed by Servier. 


\section{References}

1. Berchtold, L.A.; Prause, M.; Storling, J.; Mandrup-Poulsen, T. Cytokines and Pancreatic beta-Cell Apoptosis. Adv. Clin. Chem. 2016, 75, 99-158. [CrossRef] [PubMed]

2. Larsen, C.M.; Faulenbach, M.; Vaag, A.; Volund, A.; Ehses, J.A.; Seifert, B.; Mandrup-Poulsen, T.; Donath, M.Y. Interleukin-1-receptor antagonist in type 2 diabetes mellitus. N. Engl. J. Med. 2007, 356, 1517-1526. [CrossRef] [PubMed]

3. Larsen, C.M.; Faulenbach, M.; Vaag, A.; Ehses, J.A.; Donath, M.Y.; Mandrup-Poulsen, T. Sustained Effects of Interleukin-1 Receptor Antagonist Treatment in Type 2 Diabetes. Diabetes Care 2009, 32, 1663-1668. [CrossRef] [PubMed]

4. Mandrup-Poulsen, T.; Pickersgill, L.; Donath, M.Y. Blockade of interleukin 1 in type 1 diabetes mellitus. Nat. Rev. Endocrinol. 2010, 6, 158-166. [CrossRef] [PubMed]

5. Moran, A.; Bundy, B.; Becker, D.J.; DiMeglio, L.A.; Gitelman, S.E.; Goland, R.; Greenbaum, C.J.; Herold, K.C.; Marks, J.B.; Raskin, P.; et al. Interleukin-1 antagonism in type 1 diabetes of recent onset: Two multicentre, randomised, double-blind, placebo-controlled trials. Lancet 2013, 381, 1905-1915. [CrossRef]

6. Cabrera, S.M.; Wang, X.; Chen, Y.G.; Jia, S.; Kaldunski, M.L.; Greenbaum, C.J.; Type 1 Diabetes TrialNet Canakinumab Study Group; Mandrup-Poulsen, T.; The AIDA Study Group; Hessner, M.J. Interleukin-1 antagonism moderates the inflammatory state associated with Type 1 diabetes during clinical trials conducted at disease onset. Eur. J. Immunol. 2016, 46, 1030-1046. [CrossRef]

7. Mastrandrea, L.; Yu, J.; Behrens, T.; Buchlis, J.; Albini, C.; Fourtner, S.; Quattrin, T. Etanercept treatment in children with new-onset type 1 diabetes: Pilot randomized, placebo-controlled, double-blind study. Diabetes Care 2009, 32, 1244-1249. [CrossRef] [PubMed]

8. Ablamunits, V.; Henegariu, O.; Hansen, J.B.; Opare-Addo, L.; Preston-Hurlburt, P.; Santamaria, P.; Mandrup-Poulsen, T.; Herold, K.C. Synergistic reversal of type 1 diabetes in NOD mice with anti-CD3 and interleukin-1 blockade: Evidence of improved immune regulation. Diabetes 2012, 61, 145-154. [CrossRef]

9. Cigliola, V.; Chellakudam, V.; Arabieter, W.; Meda, P. Connexins and beta-cell functions. Diabetes Res. Clin. Pract. 2013, 99, 250-259. [CrossRef]

10. Klee, P.; Allagnat, F.; Pontes, H.; Cederroth, M.; Charollais, A.; Caille, D.; Britan, A.; Haefliger, J.A.; Meda, P. Connexins protect mouse pancreatic beta cells against apoptosis. J. Clin. Investig. 2011, 121, 4870-4879. [CrossRef]

11. Farnsworth, N.L.; Benninger, R.K. New insights into the role of connexins in pancreatic islet function and diabetes. FEBS Lett. 2014, 588, 1278-1287. [CrossRef] [PubMed]

12. Ravier, M.A.; Guldenagel, M.; Charollais, A.; Gjinovci, A.; Caille, D.; Sohl, G.; Wollheim, C.B.; Willecke, K.; Henquin, J.C.; Meda, P. Loss of connexin36 channels alters $\beta$-cell coupling, islet synchronization of glucose-induced $\mathrm{Ca}^{2+}$ and insulin oscillations, and basal insulin release. Diabetes 2005, 54, 1798-1807. [CrossRef] [PubMed]

13. Potolicchio, I.; Cigliola, V.; Velazquez-Garcia, S.; Klee, P.; Valjevac, A.; Kapic, D.; Cosovic, E.; Lepara, O.; Hadzovic-Dzuvo, A.; Mornjacovic, Z.; et al. Connexin-dependent signaling in neuro-hormonal systems. Biochim. Biophys. Acta 2012, 1818, 1919-1936. [CrossRef] [PubMed]

14. Meda, P.; Pepper, M.S.; Traub, O.; Willecke, K.; Gros, D.; Beyer, E.; Nicholson, B.; Paul, D.; Orci, L. Differential expression of gap junction connexins in endocrine and exocrine glands. Endocrinology 1993, 133, 2371-2378. [CrossRef]

15. Serre-Beinier, V.; Mas, C.; Calabrese, A.; Caton, D.; Bauquis, J.; Caille, D.; Charollais, A.; Cirulli, V.; Meda, P. Connexins and secretion. Biol. Cell 2002, 94, 477-492. [CrossRef]

16. Moller, S.; Jacobsen, J.C.B.; Braunstein, T.H.; Holstein-Rathlou, N.H.; Sorensen, C.M. Influence of connexin45 on renal autoregulation. Am. J. Physiol. Renal Physiol. 2020, 318, F732-F740. [CrossRef]

17. Yang, W.; Lampe, P.D.; Kensel-Hammes, P.; Hesson, J.; Ware, C.B.; Crisa, L.; Cirulli, V. Connexin 43 Functions as a Positive Regulator of Stem Cell Differentiation into Definitive Endoderm and Pancreatic Progenitors. iScience 2019, 19, 450-460. [CrossRef]

18. Carvalho, C.P.; Barbosa, H.C.; Britan, A.; Santos-Silva, J.C.; Boschero, A.C.; Meda, P.; Collares-Buzato, C.B. Beta cell coupling and connexin expression change during the functional maturation of rat pancreatic islets. Diabetologia 2010, 53, 1428-1437. [CrossRef] 
19. Klee, P.; Lamprianou, S.; Charollais, A.; Caille, D.; Sarro, R.; Cederroth, M.; Haefliger, J.A.; Meda, P. Connexin implication in the control of the murine beta-cell mass. Pediatr. Res. 2011, 70, 142-147. [CrossRef]

20. Vozzi, C.; Bosco, D.; Dupont, E.; Charollais, A.; Meda, P. Hyperinsulinemia-induced hypoglycemia is enhanced by overexpression of connexin 43. Endocrinology 1997, 138, 2879-2885. [CrossRef]

21. Vozzi, C.; Ullrich, S.; Charollais, A.; Philippe, J.; Orci, L.; Meda, P. Adequate connexin-mediated coupling is required for proper insulin production. J. Cell Biol. 1995, 131, 1561-1572. [CrossRef] [PubMed]

22. Collares-Buzato, C.B.; Leite, A.R.; Boschero, A.C. Modulation of gap and adherens junctional proteins in cultured neonatal pancreatic islets. Pancreas 2001, 23, 177-185. [CrossRef] [PubMed]

23. Serre-Beinier, V.; Le Gurun, S.; Belluardo, N.; Trovato-Salinaro, A.; Charollais, A.; Haefliger, J.A.; Condorelli, D.F.; Meda, P. Cx36 preferentially connects beta-cells within pancreatic islets. Diabetes 2000, 49, 727-734. [CrossRef] [PubMed]

24. Theis, M.; Mas, C.; Doring, B.; Degen, J.; Brink, C.; Caille, D.; Charollais, A.; Kruger, O.; Plum, A.; Nepote, V.; et al. Replacement by a lacZ reporter gene assigns mouse connexin 36,45 and 43 to distinct cell types in pancreatic islets. Exp. Cell Res. 2004, 294, 18-29. [CrossRef]

25. Short, K.W.; Head, W.S.; Piston, D.W. Connexin 36 mediates blood cell flow in mouse pancreatic islets. Am. J. Physiol. Endocrinol. Metab. 2014, 306, E324-E331. [CrossRef]

26. Haugan, K.; Olsen, K.B.; Hartvig, L.; Petersen, J.S.; Holstein-Rathlou, N.H.; Hennan, J.K.; Nielsen, M.S. The antiarrhythmic peptide analog ZP123 prevents atrial conduction slowing during metabolic stress. J. Cardiovasc. Electrophysiol. 2005, 16, 537-545. [CrossRef]

27. Dhein, S.; Larsen, B.D.; Petersen, J.S.; Mohr, F.W. Effects of the new antiarrhythmic peptide ZP123 on epicardial activation and repolarization pattern. Cell Commun. Adhes. 2003, 10, 371-378. [CrossRef]

28. Axelsen, L.N.; Stahlhut, M.; Mohammed, S.; Larsen, B.D.; Nielsen, M.S.; Holstein-Rathlou, N.H.; Andersen, S.; Jensen, O.N.; Hennan, J.K.; Kjolbye, A.L. Identification of ischemia-regulated phosphorylation sites in connexin43: A possible target for the antiarrhythmic peptide analogue rotigaptide (ZP123). J. Mol. Cell. Cardiol. 2006, 40, 790-798. [CrossRef]

29. Stahlhut, M.; Petersen, J.S.; Hennan, J.K.; Ramirez, M.T. The antiarrhythmic peptide rotigaptide (ZP123) increases connexin 43 protein expression in neonatal rat ventricular cardiomyocytes. Cell Commun. Adhes. 2006, 13, 21-27. [CrossRef]

30. Hao, J.L.; Suzuki, K.; Lu, Y.; Hirano, S.; Fukuda, K.; Kumagai, N.; Kimura, K.; Nishida, T. Inhibition of gap junction-mediated intercellular communication by TNF-alpha in cultured human corneal fibroblasts. Investig. Ophthalmol. Vis. Sci. 2005, 46, 1195-1200. [CrossRef]

31. Retamal, M.A.; Froger, N.; Palacios-Prado, N.; Ezan, P.; Saez, P.J.; Saez, J.C.; Giaume, C. Cx43 hemichannels and gap junction channels in astrocytes are regulated oppositely by proinflammatory cytokines released from activated microglia. J. Neurosci. 2007, 27, 13781-13792. [CrossRef] [PubMed]

32. Segerstolpe, A.; Palasantza, A.; Eliasson, P.; Andersson, E.M.; Andreasson, A.C.; Sun, X.; Picelli, S.; Sabirsh, A.; Clausen, M.; Bjursell, M.K.; et al. Single-Cell Transcriptome Profiling of Human Pancreatic Islets in Health and Type 2 Diabetes. Cell Metab. 2016, 24, 593-607. [CrossRef] [PubMed]

33. Hahn, W.S.; Kuzmicic, J.; Burrill, J.S.; Donoghue, M.A.; Foncea, R.; Jensen, M.D.; Lavandero, S.; Arriaga, E.A.; Bernlohr, D.A. Proinflammatory cytokines differentially regulate adipocyte mitochondrial metabolism, oxidative stress, and dynamics. Am. J. Physiol. Endocrinol. Metab. 2014, 306, E1033-E1045. [CrossRef] [PubMed]

34. Funakoshi-Tago, M.; Tago, K.; Andoh, K.; Sonoda, Y.; Tominaga, S.; Kasahara, T. Functional role of c-Src in IL-1-induced NF-kappa B activation: c-Src is a component of the IKK complex. J. Biochem. 2005, 137, 189-197. [CrossRef] [PubMed]

35. Xie, X.; Lan, T.; Chang, X.; Huang, K.; Huang, J.; Wang, S.; Chen, C.; Shen, X.; Liu, P.; Huang, H. Connexin 43 mediates NF-kappaB signalling activation induced by high glucose in GMCs: Involvement of c-Src. Cell Commun. Signal. 2013, 11, 38. [CrossRef]

36. Berthoud, V.M.; Minogue, P.J.; Laing, J.G.; Beyer, E.C. Pathways for degradation of connexins and gap junctions. Cardiovasc. Res. 2004, 62, 256-267. [CrossRef]

37. Musil, L.S.; Le, A.C.; VanSlyke, J.K.; Roberts, L.M. Regulation of connexin degradation as a mechanism to increase gap junction assembly and function. J. Biol. Chem. 2000, 275, 25207-25215. [CrossRef] 
38. Storling, J.; Zaitsev, S.V.; Kapelioukh, I.L.; Karlsen, A.E.; Billestrup, N.; Berggren, P.O.; Mandrup-Poulsen, T. Calcium has a permissive role in interleukin-1beta-induced c-jun $\mathrm{N}$-terminal kinase activation in insulin-secreting cells. Endocrinology 2005, 146, 3026-3036. [CrossRef]

39. Sekine, N.; Fasolato, C.; Pralong, W.F.; Theler, J.M.; Wollheim, C.B. Glucose-induced insulin secretion in INS-1 cells depends on factors present in fetal calf serum and rat islet-conditioned medium. Diabetes 1997, 46, 1424-1433. [CrossRef]

40. Poitout, V.; Amyot, J.; Semache, M.; Zarrouki, B.; Hagman, D.; Fontes, G. Glucolipotoxicity of the pancreatic beta cell. Biochim. Biophys. Acta 2010, 1801, 289-298. [CrossRef]

41. Bugliani, M.; Syed, F.; Masini, M.; Marselli, L.; Suleiman, M.; Novelli, M.; Filipponi, F.; Boggi, U.; Masiello, P.; De Tata, V.; et al. Direct effects of rosuvastatin on pancreatic human beta cells. Acta Diabetol. 2013, 50, 983-985. [CrossRef] [PubMed]

42. Storling, J.; Binzer, J.; Andersson, A.K.; Zullig, R.A.; Tonnesen, M.; Lehmann, R.; Spinas, G.A.; Sandler, S.; Billestrup, N.; Mandrup-Poulsen, T. Nitric oxide contributes to cytokine-induced apoptosis in pancreatic beta cells via potentiation of JNK activity and inhibition of Akt. Diabetologia 2005, 48, 2039-2050. [CrossRef] [PubMed]

43. Hansen, J.B.; Tonnesen, M.F.; Madsen, A.N.; Hagedorn, P.H.; Friberg, J.; Grunnet, L.G.; Heller, R.S.; Nielsen, A.O.; Storling, J.; Baeyens, L.; et al. Divalent metal transporter 1 regulates iron-mediated ROS and pancreatic beta cell fate in response to cytokines. Cell Metab. 2012, 16, 449-461. [CrossRef] [PubMed]

44. Ghiasi, S.M.; Krogh, N.; Tyrberg, B.; Mandrup-Poulsen, T. The No-Go and Nonsense-Mediated RNA Decay Pathways Are Regulated by Inflammatory Cytokines in Insulin-Producing Cells and Human Islets and Determine beta-Cell Insulin Biosynthesis and Survival. Diabetes 2018, 67, 2019-2037. [CrossRef] [PubMed]

45. Lundh, M.; Christensen, D.P.; Rasmussen, D.N.; Mascagni, P.; Dinarello, C.A.; Billestrup, N.; Grunnet, L.G.; Mandrup-Poulsen, T. Lysine deacetylases are produced in pancreatic beta cells and are differentially regulated by proinflammatory cytokines. Diabetologia 2010, 53, 2569-2578. [CrossRef]

46. Kekow, J.; Ulrichs, K.; Muller-Ruchholtz, W.; Gross, W.L. Measurement of rat insulin. Enzyme-linked immunosorbent assay with increased sensitivity, high accuracy, and greater practicability than established radioimmunoassay. Diabetes 1988, 37, 321-326. [CrossRef]

47. Ghiasi, S.M.; Dahllof, M.S.; Osmai, Y.; Osmai, M.; Jakobsen, K.K.; Aivazidis, A.; Tyrberg, B.; Perruzza, L.; Prause, M.C.B.; Christensen, D.P.; et al. Regulation of the beta-cell inflammasome and contribution to stress-induced cellular dysfunction and apoptosis. Mol. Cell. Endocrinol. 2018, 478, 106-114. [CrossRef] 